\section{Evidence of Zika Virus Infection in Brain and Placental Tissues from Two Congenitally Infected Newborns and Two Fetal Losses - Brazil, 2015}

Roosecelis Brasil Martines, $\mathrm{MD}, \mathrm{PhD}^{1}$; Julu Bhatnagar, $\mathrm{PhD}^{1}$; M. Kelly Keating, $\mathrm{DVM}^{1}$; Luciana Silva-Flannery, $\mathrm{PhD}^{1}$; Atis Muehlenbachs, $\mathrm{MD}, \mathrm{PhD}^{1}$; Joy Gary, DVM, $\mathrm{PhD}^{1}$; Cynthia Goldsmith, $\mathrm{MS}^{1}$; Gillian Hale, $\mathrm{MD}^{1}$; Jana Ritter, $\mathrm{DVM}^{1}$; Dominique Rollin, $\mathrm{MD}^{1}$; Wun-Ju Shieh, MD, $\mathrm{PhD}^{1}$; Kleber G. Luz, MD, $\mathrm{PhD}^{2}$; Ana Maria de Oliveira Ramos, MD, $\mathrm{PhD}^{3}$; Helaine Pompeia Freire Davi, MD, $\mathrm{PhD}^{4}$; Wanderson Kleber de Oliveria, $\mathrm{MD}^{5}$; Robert Lanciotti, $\mathrm{PhD}^{6}$; Amy Lambert, $\mathrm{PhD}^{6}$; Sherif Zaki, MD, $\mathrm{PhD}^{1}$

On February 10, 2016, this report was posted as an MMWR Early Release on the MMWR website (http://www.cdc.gov/mmwr).

Zika virus is a mosquito-borne flavivirus that is related to dengue virus and transmitted primarily by Aedes aegypti mosquitoes, with humans acting as the principal amplifying host during outbreaks. Zika virus was first reported in Brazil in May 2015 (1). By February 9, 2016, local transmission of infection had been reported in 26 countries or territories in the Americas.* Infection is usually asymptomatic, and, when symptoms are present, typically results in mild and self-limited illness with symptoms including fever, rash, arthralgia, and conjunctivitis. However, a surge in the number of children born with microcephaly was noted in regions of Brazil with a high prevalence of suspected Zika virus disease cases. More than 4,700 suspected cases of microcephaly were reported from mid-2015 through January 2016, although additional investigations might eventually result in a revised lower number (2). In response, the Brazil Ministry of Health established a task force to further investigate possible connections between the virus and brain anomalies in infants (3).

Since November 2015, CDC has been developing assays for Zika virus testing in formalin-fixed, paraffin-embedded (FFPE) tissue samples. In December 2015, FFPE tissues samples from two newborns (born at 36 and 38 weeks gestation) with microcephaly who died within 20 hours of birth and two miscarriages (fetal losses at 11 and 13 weeks) were submitted to CDC, from the state of Rio Grande do Norte in Brazil, for histopathologic evaluation and laboratory testing for suspected Zika virus infection. All four mothers had clinical signs of Zika virus infection, including fever and rash, during the first trimester of pregnancy, but did not have clinical signs of active infection at the time of delivery or miscarriage. The mothers were not tested for antibodies to Zika virus. Samples included brain and other autopsy tissues from the two

\footnotetext{
* Updated information about local transmission of Zika virus is available online (http://www.cdc.gov/zika/geo/index.html).
}

newborns, a placenta from one of the newborns, and products of conception from the two miscarriages.

FFPE tissues were tested by Zika virus reverse transcriptionpolymerase chain reaction (RT-PCR) targeting the nonstructural protein 5 and envelope genes using general methods for RT-PCR (4), and by immunohistochemistry using a mouse polyclonal anti-Zika virus antibody, using methods previously described (5). Specific specimens from all four cases were positive by RT-PCR, and sequence analysis provided further evidence of Zika virus infection, revealing highest identities with Zika virus strains isolated from Brazil during 2015. In the newborns, only brain tissue was positive by RT-PCR assays. Specimens from two of the four cases were positive by immunohistochemistry: viral antigen was noted in mononuclear cells (presumed to be glial cells and neurons within the brain) of one newborn, and within the chorionic villi from one of the miscarriages. Testing for dengue virus was negative by RT-PCR in specimens from all cases.

For both newborns, significant histopathologic changes were limited to the brain, and included parenchymal calcification, microglial nodules, gliosis, and cell degeneration and necrosis. Other autopsy tissues and placenta had no significant findings. Tests for toxoplasmosis, rubella, cytomegalovirus, herpes simplex, and HIV were negative in the two mothers who experienced miscarriages. Placental tissue from one miscarriage showed heterogeneous chorionic villi with calcification, fibrosis, perivillous fibrin deposition, and patchy intervillositis and focal villitis, while tissue from the other miscarriage had sparsely sampled normal-appearing chorionic villi.

This report describes evidence of a link between Zika virus infection and microcephaly and fetal demise through detection of viral RNA and antigens in brain tissues from infants with microcephaly and placental tissues from early miscarriages. Histopathologic findings indicate the presence of Zika virus in fetal tissues. These findings also suggest brain and early gestational placental tissue might be the preferred tissues for postmortem viral diagnosis. Nonfrozen, formalin-fixed specimens or FFPE blocks are the preferred sample type for histopathologic evaluation and immunohistochemistry, and RT-PCR can be performed on either fresh frozen or formalinfixed specimens. To better understand the pathogenesis of Zika virus infection and associated congenital anomalies and fetal death, it is necessary to evaluate autopsy and placental tissues from additional cases, and to determine the effect of gestational age during maternal illness on fetal outcomes. 


\begin{abstract}
${ }^{1}$ Infectious Diseases Pathology Branch, Division of High-Consequence Pathogens and Pathology, National Center for Emerging and Zoonotic Infectious Diseases (NCEZID), CDC; ${ }^{2}$ Department of Infectious Diseases, Federal University of Rio Grande do Norte, Natal, RN, Brazil; ${ }^{3}$ Department of Pathology, Federal University of Rio Grande do Norte, Natal, Brazil; ${ }^{4}$ Service for Ascertaining Death in the State of Rio Grande do Norte (SVO/RN), Natal/ RN, Brazil; ${ }^{5}$ Ministry of Health, Brazil; ${ }^{6}$ Arboviral Diseases Branch, Division of Vector-Borne Diseases, NCEZID, CDC.
\end{abstract}

Corresponding author: Roosecelis Brasil Martines, RBrasilMartines@cdc.gov, 404-639-3886.

\section{References}

1. Zanluca C, de Melo VC, Mosimann ALP, Dos Santos GI, Dos Santos $\mathrm{CN}$, Luz K. First report of autochthonous transmission of Zika virus in Brazil. Mem Inst Oswaldo Cruz 2015;110:569-72. http://dx.doi. org/10.1590/0074-02760150192.
2. Victoria CG, Schuler-Faccini L, Matijasevich A, Ribeiro E, Pessoa A, Barros FC. Microcephaly in Brazil: how to interpret reported numbers? Lancet 2016. Epub February 5, 2016. http://dx.doi.org/10.1016/ S0140-6736(16)00273-7.

3. Schuler-Faccini L, Ribeiro EM, Feitosa IML, et al.; Brazilian Medical Genetics Society-Zika Embryopathy Task Force. Possible association between Zika virus infection and microcephaly-Brazil, 2015. MMWR Morb Mortal Wkly Rep 2016;65:59-62. http://dx.doi.org/10.15585/ mmwr.mm6503e2.

4. Bhatnagar J, Blau DM, Shieh WJ, et al. Molecular detection and typing of dengue viruses from archived tissues of fatal cases by rt-PCR and sequencing: diagnostic and epidemiologic implications. Am J Trop Med Hyg 2012;86:335-40. http://dx.doi.org/10.4269/ajtmh.2012.11-0346.

5. Shieh WJ, Blau DM, Denison AM, et al. 2009 pandemic influenza A (H1N1): pathology and pathogenesis of 100 fatal cases in the United States. Am J Pathol 2010;177:166-75. http://dx.doi.org/10.2353/ ajpath.2010.100115. 